\title{
Easiness in Money Transfer Post Implementation of Internet Facilities
}

\author{
R. Vasuki, M. Sankar, N. Mathan Kumar
}

\begin{abstract}
The budgetary changes that were started in the mid 90's and the globalization and advancement measures got a totally new working condition to the banks. Administrations and items like "Anyplace Banking", "Tele Banking", "Web Banking", "web Banking", :E-Banking", and so forth have become the trendy expressions of the day and the banks are attempting to adapt to the challenge by offering imaginative and alluringly bundled innovation administrations to their customers. E - Banking, The Government of India established the Information Technology Act, 2008 by and large known as IT Act, 2008 with impact from the fifth February 2008 to give lawful acknowledgment to electronic exchanges and different methods for Electronics business.

Several public sector banks have earmarked substantive budgets and are drawing up IT strategies to face the future challenges. At this juncture the study of awareness of the Internet Banking is attempted to know the current scenario so as to plan properly for the future.
\end{abstract}

Keywords - Public Sector, Information Technology act, Electronic Business.

\section{INTRODUCTION}

Universal exchange alludes to the exchange crosswise over national limits. The developing volumes of worldwide exchange and bringing down of exchange obstructions have activated discussion and examination on the effect of universal exchange on financial development of nations. nations will in general be more gainful than nations which produce for the residential market. The connection between global exchange and financial development of a nation can be either positive or negative, what decides the idea of the relationship is the monetary systems set up to deal with the exchange[1]-[3].

\section{OBJECTIVES}

The Study aimed to probe into the following objectives. 1. To study the awareness level of customers regarding the Internet banking.

Revised Manuscript Received on December 16, 2019

R.Vasuki, Department of Science and Humanities, Bharath Institute of Higher Education and Research, Chennai , India. Email: vasukiteacher@gmail.com

M.Sankar, Department of Science and Humanities, Bharath Institute of Higher Education and Research, Chennai, India. Email: sankar06.phd@gmail.com

N. Mathankumar, Department of Science and Humanities, Bharath Institute of Higher Education and Research, Chennai, India. Email: ma.aswinkumar18@gmail.com Verifiable approval has uncovered that universally dynamic

2. To analyse the attitude of the customers towards the sevice rendered by the Internet banking.

3. To study the customer satisfaction about Internet banking.

4. To list out the services rendered by banks in regard to the Internet banking[4]-[7].

\section{METHODOLOGY}

\section{A. Sampling design}

The convenience sampling technique has been adopted and 160 respondents have been taken as samples from Chennai city for the present study, due consideration has been given to draw respondents from professionals, pensioners, Business persons and others[8]-[12].

\section{B. Area of the study and period of the study}

The area covered for the study is Chennai city. The period of the study is March to August.

\section{Limitation of the study}

1. The study has been restricted to Chennai city owing to time and cost constraints.

2 . The customers are not less interested in answering the Questionnaire, as it hinders their work the responses given by them as such is taken for analysis, so the findings cannot be generalized.

3. Due to time constraints the sample size is restricted to 160

\section{RESULTS AND DISCUSSIONS}

It is observed from the results and discussion that majority of the Internet banking users are, married, educated, male in the age group 25 years and above doing business or professionals earning Rs.10,000 and above are the profile of the Internet banking users.

1. $(21.50 \%)$ of the respondents are the customers of State Bank of India and Indian Bank.

2. It is found that majority $(48.75 \%)$ of the respondents are having the experience for a period of "Less than one" year.

3 . The mostly used services in Internet banking is account enquiry

4. It is found that the order of the reason the Internet banking are "Low cost" "available all the time", "save time" and "quick and accurate communication".

5. It is found that majority ( $55 \%$ ) of the respondents have felt that the Internet banking is a useful device for small level to the common man.

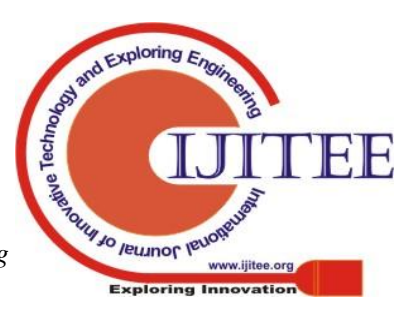


6. It is found that majority $(47.50 \%)$ of the respondents using online transaction felt that it is convenient[13]-[18].

7. It is found that majority ( $40 \%$ ) of the respondents have felt that security of online transactions are highly secured.

8 . It is found that majority $(51.25 \%)$ of the respondents have felt that safety provisions of Internet banking are "high".

9. It is found that majority $(62.50 \%)$ of the respondents have felt that services rendered by Internet banking transactions are Excellent.

10. Majority (45\%) of the respondents have that Internet banking charges are low.

11. It is found that majority $(51.25 \%)$ of the respondents are highly satisfied.

12. (66.67\%) of the respondents have got high level satisfaction from the Account enquiry service.

13. $(50 \%)$ of the respondents have derived high satisfaction from fund transfer service[19]-[20].

14. It is found that majority (50\%) of the respondents have got medium level satisfaction from E-bill presentment and payment.

15. It is found that majority of the respondents are satisfied due to the low cost of operation.

16. It is found that the order of the cause for dissatisfaction is "Needs a computer", "Safety Problem", "Lack of knowledge" respectively.

17. It is found that the order of reason for dissatisfactions are found to be technical problem, slow browsing, current cut off.

\section{RESULTS AND DISCUSSIONS}

The following suggestions are offered to the Banks.

1. Banks have to take steps to increase the awareness level of the customers through newspaper and magazines[21]-[23].

2 . The security system of the service may be improved.

3. The bankers have to take a comprehensive view about their delivery channels. It should not only be viewed in terms of cost and technology but focushing mainly on time, place and advantage to the customers.

4. Higher electronic transaction volumes will boost profits. Banks can use current infrastructure. Another method is beater risk management. Technology is I place to make this happen new infrastructure, supporting single point authorization and sophisticated decision making techniques. By finding about customer risks, banks can manage these risks more effectively and get greater profits

5. The company can provide users manuals to the customers at their request Internet banking transaction to the operate[24]-[25].

\section{CONCLUSION}

The study reveals that account enquiry is the mostly used service of the Internet Banking and low cost is the reason for using the Internet Banking. Majority of the respondents have felt the on live transactions are convenient and highly secured, safety provisions are high and the services rendered are excellent. The respondents are highly satisfied.

\section{REFERENCES}

1) Vasanthi, S. \& Rabiyathul Basariya, S. 2019, "Influence of value analysis and cross training in industry", International Journal of Engineering and Advanced Technology, vol. 8, no. 6, pp. 1810-1811.

2) Velvizhi, R., Sri Gowtham, S. \& Jeya Priya, D. 2019, "Examination of early feedbacks for effective product retailing on E-commerce websites", International Journal of Engineering and Advanced Technology, vol. 8, no. 6 Special Issue 2, pp. 703-706.

3) Anuradha, C., Pothumani, S. \& Kavitha, R. 2019, "A novel method towards E-commerce", International Journal of Engineering and Advanced Technology, vol. 8, no. 6 Special Issue 2, pp. 535-538.

4) Thomas, J. \& Rabiyathul Basariya, S. 2019, "A study on the issues of financial ratio analysis", Indian Journal of Public Health Research and Development, vol. 10, no. 3, pp. 1079-1081.

5) Ramachandran, S. \& Rabiyathul Basariya, S. 2019, "Online marketing study on customer satisfaction and relationship", Indian Journal of Public Health Research and Development, vol. 10, no. 3, pp. 1072-1078.

6) Priya, R., Vinothini, G. \& Cor Jesu, C.D. 2019, "The mentor-protégé relationship for professional growth", Journal of Advanced Research in Dynamical and Control Systems, vol. 11, no. 9 Special Issue, pp. 1110-1119.

7) Jannifer Rani, N., Bina Pani, S. \& Nimisha, N.S. 2019, "A study on money back polices available in LIC", Journal of Advanced Research in Dynamical and Control Systems, vol. 11, no. 9 Special Issue, pp. 833-839

8) Saillaja, V., Jhansi Rani, K. \& Catherine, R. 2019, "Global marketing management planning and organization", Journal of Advanced Research in Dynamical and Control Systems, vol. 11, no. 9 Special Issue, pp. 489-493.

9) Saillaja, V., Jhansi Rani, K. \& Catherine, R. 2019, "The new phase of marketing information system", Journal of Advanced Research in Dynamical and Control Systems, vol. 11, no. 9 Special Issue, pp. 482-488.

10) Thoufiqulla \& Raju, D.V. 2019, "Perception of indian investor towards investment in mutual funds with special reference to mip funds", Journal of Advanced Research in Dynamical and Control Systems, vol. 11, no. 5, pp. 177-183.

11) Jasmine, K.R.M. \& Basariya, S.R. 2018, "A study on the customers benefits on mutual funds", International Journal of Civil Engineering and Technology, vol. 9 , no. 4 , pp. $45-48$.

12) Vasanthi, S. \& Basariya, S.R. 2019, "Pros and cons of on the job training versus off the job training", International Journal of Scientific and Technology Research, vol. 8, no. 10, pp. 671-674.

13) Pavithra, J. \& Ganesan, M. 2016, "A study on awareness and impact of micro-financial schemes", International Journal of Applied Business and Economic Research, vol. 14, no. 8, pp. 5449-5460.

14) Pavithra, J., Dilli Babu, P. \& Ambuli, T.V. 2014, "A study on budgetary control at Maruti Service Masters, Chennai", International Journal of Applied Business and Economic Research, vol. 12, no. 2, pp. 151-161.

15) Gunaraja, T.M. \& Venkatrama Raju, D. 2018, "Determining factors of organisational climate with reference to leadership styles", International Journal of Mechanical Engineering and Technology, vol. 9, no. 9, pp. 1327-1332.

16) Gunaraja, T.M. \& Venkatrama Raju, D. 2018, "The role of job satisfaction and training of employees in determining organisational climate of a selected industry", International Journal of Civil Engineering and Technology, vol. 9, no. 8, pp. 1266-1269.

17) Aarathy, T.S. \& Raju, D.V. 2018, "Performance appraisal and its effects on employees with respect to it sector in Chennai city", International Journal of Civil Engineering and Technology, vol. 9, no. 6, pp. 1535-1538.

18) Aarathy, T.S. \& Raju, D.V. 2018, "Employee perception towards performance appraisal system in IT sector", International Journal of Mechanical Engineering and Technology, vol. 9, no. 5, pp. 131-135.

19) Porselvi, W., Jublee, D. \& Sivanesan, G. 2018, "A study on factors influencing adoption of technology and innovation in banking industry, tamilnadu, India", International Journal of Mechanical Engineering and Technology, vol. 9, no. 5, pp. 789-800.

20) Akessa, G.M. and Dhufera, A.G., 2015. Factors That Influences Students Academic Performance: A Case of Rift Valley University, Jimma, Ethiopia. Journal of Education and Practice, 6(22), pp.55-63.

21) Miller, G. and Shih, C.C., 1999. A faculty assessment of the academic 
rigor of on-and off-campus courses in agriculture. Journal of Agricultural Education, 40, pp.57-65.

22) Tsinidou, M., Gerogiannis, V. and Fitsilis, P., 2010. Evaluation of the factors that determine quality in higher education: an empirical study. Quality Assurance in education, 18(3), pp.227-244.

23) Farooq, M.S., Chaudhry, A.H., Shafiq, M. and Berhanu, G., 2011. Factors affecting students' quality of academic performance: a case of secondary school level. Journal of quality and technology management, 7(2), pp.1-14.

24) Fitsilis, P., Gerogiannis, V. and Anthopoulos, L., 2014. Ontologies for software project management: a review. Journal of Software Engineering and Applications, 7(13), p.1096.

25) Adams, J.D. and Jaffe, A.B., 1996. Bounding the effects of R\&D: an investigation using matched establishment-firm data(No. w5544). National bureau of economic research.

\section{AUTHORS PROFILE}

R.Vasuki Assistant Professor, Department of Science and Humanities, Bharath Institute of Higher Education and Research, Chennai, India.

M.Sankar Assistant Professor, Department of Science and Humanities, Bharath Institute of Higher Education and Research, Chennai , India.

N. Mathankumar Assistant Professor, Department of Science and Humanities, Bharath Institute of Higher Education and Research, Chennai, India. 